\title{
Modulating cell response on cellulose surfaces; tunable attachment and scaffold mechanics
}

\author{
James C. Courtenay $\cdot$ Christoph Deneke $\cdot$ Evandro M. Lanzoni • \\ Carlos A. Costa $\cdot$ Yongho Bae $\cdot$ Janet L. Scott $\cdot$ Ram I. Sharma
}

Received: 19 October 2017/ Accepted: 11 December 2017/Published online: 19 December 2017

(C) The Author(s) 2017. This article is an open access publication

\begin{abstract}
Combining surface chemical modification of cellulose to introduce positively charged trimethylammonium groups by reaction with glycidyltrimethylammonium chloride (GTMAC) allowed for direct attachment of mammalian MG-63 cells, without addition of protein modifiers, or ligands. Very small increases in the surface charge resulted in significant increases in cell attachment: at a degree of substitution (DS) of only $1.4 \%$, MG-63 cell attachment was $>90 \%$ compared to tissue culture plastic, whereas minimal attachment occurred on unmodified cellulose. Cell attachment plateaued above DS of ca. $1.85 \%$ reflecting a similar trend in surface charge, as determined from $\zeta$-potential measurements and
\end{abstract}

Electronic supplementary material The online version of this article (https://doi.org/10.1007/s10570-017-1612-3) contains supplementary material, which is available to authorized users.

J. C. Courtenay · J. L. Scott $(\varangle) \cdot$ R. I. Sharma $(\square)$

Centre for Sustainable Chemical Technologies, University of Bath, Bath BA2 7AY, UK

e-mail: j.1.scott@bath.ac.uk

R. I. Sharma

e-mail: r.sharma@bath.ac.uk

J. C. Courtenay · J. L. Scott

Department of Chemistry, University of Bath,

Bath BA2 7AY, UK

R. I. Sharma

Department of Chemical Engineering, University of Bath, Bath BA2 7AY, UK capacitance coupling (electric force microscopy). Cellulose film stiffness was modulated by cross linking with glyoxal (0.3-2.6\% degree of crosslinking) to produce a range of materials with surface shear moduli from 76 to $448 \mathrm{kPa}$ (measured using atomic force microscopy). Cell morphology on these materials could be regulated by tuning the stiffness of the scaffolds. Thus, we report tailored functionalised biomaterials based on cationic cellulose that can be tuned through surface reaction and glyoxal crosslinkin $+\mathrm{g}$, to influence the attachment and morphology of cells. These scaffolds are the first steps towards materials designed to support cells and to regulate cell morphology on implanted biomaterials using only scaffold and cells, i.e. without added adhesion promoters.

\footnotetext{
C. Deneke - E. M. Lanzoni - C. A. Costa

National Nanotechnology Laboratory, Centre for National Research in Energy and Materials, Campinas, São Paulo, Brazil

Y. Bae

Department of Pathology and Anatomical Sciences, Jacobs School of Medicine and Biomedical Sciences, University at Buffalo, The State University of New York, Buffalo, NY 14214, USA
} 
Keywords Tunable tissue scaffold $\cdot$ Cellulose $\cdot$ Cell response $\cdot$ Chemical modification $\cdot$ Simple manufacture

\section{Introduction}

The development of functional substitutes for damaged tissue and organs is an aim of tissue engineering (Dvir et al. 2011). This approach involves isolating healthy cells from the patient and expanding them in vitro, to increase their numbers (Salgado et al. 2013). Traditionally, the cultured cells are seeded onto a ligandfunctionalised scaffold, with the ligands facilitating cell attachment (Agrawal et al. 2014a, b). Scaffolds provide a $3 \mathrm{D}$ support, often mimicking the natural extracellular matrix (ECM) of the cell, thus influencing cell behaviour and encouraging cell proliferation, differentiation and migration (Kular et al. 2014). The ECM is a structural support network that provides the 'glue' to bind cells together in tissue and consists of diverse proteins, sugars and other components.

Whether scaffolds are constructed from synthetic, or natural, biomaterials, they should be biocompatible, promote cell attachment and specialised cell functions, and, if to be implanted, be bioresorbable (Hollister et al. 2002; Agrawal and Ray 2001). Furthermore, a key challenge of tissue engineering is to design scaffolds that direct cells to attach or perform their phenotypic functions, which promote tissue functionality. Cellular responses to the substratum (attachment, proliferation and differentiation) are influenced by many factors including: surface charge (Courtenay et al. 2017; Sergeeva et al. 2016; Dadsetan et al. 2011), surface roughness (Biazar et al. 2011; Ranucci and Moghe 2001; Chang and Wang 2011), topology (Berti et al. 2013; Dugan et al. 2013), the presence of matrix proteins (Watanabe et al. 1993; Marklein and Burdick 2010; Schmedlen et al. 2002; Hersel et al. 2003), and porosity (Ninan et al. 2013; Gravel et al. 2006; Zaborowska et al. 2010), as well as the mechanical properties of the scaffold, such as Young's modulus (Cao et al. 2016; Bäckdahl et al. 2006; Georges and Janmey 2005).

Cell affinity for a biomaterial is governed by cell/matrix interactions, which result from specific recognition among cell surface adhesion receptors, i.e. integrins, and extracellular matrix (ECM) proteins (e.g. fibronectin, vitronectin, and collagen) that have a cell-binding domain containing the Arg-Gly-Asp (RGD), or similar sequence (Yang et al. 2002). A traditional technique used to improve and regulate the degree of cell attachment to a synthetic scaffold, lacking such binding sites, is to coat with cell adhesive proteins, such as collagen and fibronectin ( $\mathrm{Li}$ et al. 1996; Benoit and Anseth 2005; Patterson et al. 2010). However, this method of modification has potential disadvantages, such as control over isolation and purification-components of the modifying medium may elicit an inflammatory response and the proteins degrade over time (Hersel et al. 2003). Synthetic peptides have been developed to replace cell-binding proteins and the most commonly used peptide is RGD, which promotes integrin-cell adhesion on synthetic surfaces (Hersel et al. 2003). This can be a very effective way to facilitate cell attachment to synthetic surfaces, however, stable linking of RGD peptides to the surface is essential. In addition to proteins/peptides on surfaces, the mechanical properties of the scaffold surface govern cell-scaffold interactions. Thus, while the properties of the bulk scaffold material define the mechanical integrity of the scaffold, the mechanical properties of the material surface, to a depth of less than $1 \mathrm{~nm}$, influence cell response (Agrawal et al. 2014a, b). Surface modifications of the biomaterial allow tailoring of surface properties without impact on bulk material properties. Thus, through surface modification, the native surfaces of biomaterials can be physically, or chemically, transformed with the primary goal of engineering desired surface chemistry (Ismail et al. 2007), topology (Viswanathan et al. 2016), reactivity (Ducheyne and Qui 1999), biocompatibility (Lin et al. 2015), hydrophilicity (Yang et al. 2002), and/or charge (Courtenay et al. 2017).

Cell function on the scaffold can be directly influenced by: cell and ECM interactions modulated via transmembrane receptors (Lu et al. 2012), soluble growth factors (Lieberman et al. 2002), and the mechanical properties of the biomaterial (Reddi 2003). At the cellular level, once attached to the scaffold, cells probe its elasticity as they anchor and pull on their surrounding, receiving mechanical feedback from the ECM or substrate (Discher et al. 2005). This process is known by the term mechanotransduction and is one of the mechanism by which cells convert bio-mechanical stimuli from the scaffolds to chemical cues which direct cell responses (Wang et al. 1993). Thus, when constructing a scaffold for tissue 
engineering, the mechanical properties of the biomaterial are critical in regulating and guiding cell response. This has important implications in clinical application, for example, directing the differentiation of mesenchymal stem cell (MSCs) to generate specific tissue using scaffolds with elasticity matching that of the desired tissue type (Engler et al. 2006).

Cellulose has previously been investigated as a potential scaffold material for tissue engineering as it is biocompatible and has tunable chemical and mechanical properties (Modulevsky et al. 2014; Sannino et al. 2009; Svensson et al. 2005; Torres et al. 2012). Furthermore, cellulose nanocrystals have been incorporated into a range of composite materials as reinforcements to produce hybrid scaffolds with stiffer mechanical properties (Kumar and Gupta 2008; Kumar et al. 2014; Kumar et al. 2017a, b). While native cellulose requires the presence of matrix ligands to facilitate cell attachment due to the lack of integrin binding sites on the substrate (Wu et al. 2003; Zou et al. 2001; Pelton 2009), chemical modification may be employed to alter surface chemistry, allowing cell attachment (Courtenay et al. 2017). Scaffolds produced from cellulose can range from hard composites blended with hydroxyapatite (Jiang et al. 2008), to soft hydrogels (Torres-Rendon et al. 2015), as well as variably crosslinked materials including oxidised cellulose crosslinked with diamines (Syverud et al. 2015), or other crosslinking agents such as glyoxal, glutaraldehyde or diisocyanates (Quero et al. 2011; Puspasari et al. 2015). It is hypothesised that changing the elastic modulus of cellulose scaffolds can influence how cells respond and spread on the surface through mechanotransduction. This can be achieved through chemical crosslinking to increase the elastic modulus (Syverud et al. 2015).
Herein we describe the modulation and regulation of cellular responses through a dual approach of tuning both the chemical and mechanical properties of the cellulose-based scaffolds. Previously, we have demonstrated that surface modification, to introduce a positive surface charge to cellulose (Scheme 1), allows cell attachment in the absence of matrix ligands (Courtenay et al. 2017). Here we demonstrate the minimal level of surface modification required and combine this with modulation of the mechanical properties of the scaffold material, achieved by crosslinking with glyoxal (Ramires et al. 2010), which results in formation of acetal and hemiacetal linkages upon curing (Scheme 2) (Schramm and Rinderer 2000), yielding films with increased elastic moduli depending on degree of crosslinking (Quero et al. 2011).

Scaffold surfaces are probed using capacitance coupling and $\zeta$-potential measurements to provide a sound basis for the proposed mechanism of enhanced cell attachment through complementary ionic interactions. Furthermore, changes in elastic modulus upon crosslinking are characterised for both the bulk material and the scaffold surface and the effect of the latter on cell morphology ascertained. Key surface and structural properties: surface charge and surface shear modulus are demonstrated to modulate cell attachment and cell spreading respectively, thus enhancing understanding of the influence of scaffold surface properties on cell responses.

\section{Materials and methods}

Cellulose dialysis tubing (regenerated cellulose, MWCO 12,400 Da) from Sigma Aldrich was used a
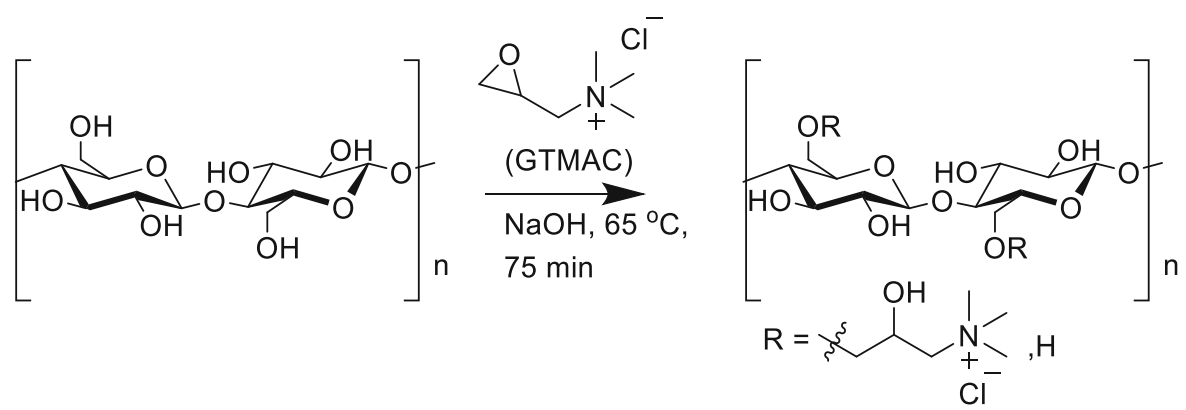

Scheme 1 Surface derivatisation of cellulose films via the cationisation of primary OH groups accessible on the film surface by GTMAC. Cationisation results in a positive surface charge on the films 

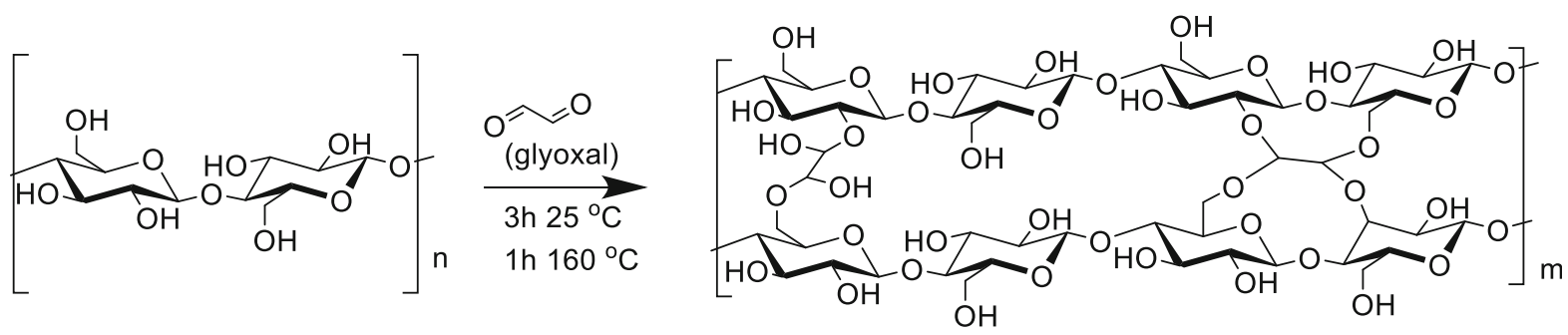

Scheme 2 Structural modification of cellulose films through acetal, or hemiacetal, linkages formed by reaction of glyoxal with the hydroxyl groups of the cellulose, leading to increased film stiffness

scaffold substrate for cell studies. For surface modifications, sodium hydroxide pellets $(\geq 98 \%$ ), glycidyltrimethylammonium chloride (GTMAC) $(\geq 90 \%), 0.1 \mathrm{M} \mathrm{AgNO}_{3}$ aqueous solution $(\geq 95 \%)$, indigo carmine powder ( $\geq 98 \%)$, and 5(6)-carboxyfluorescein $(\geq 95 \%)$ were purchased from Sigma-Aldrich and used as received. For crosslinking modifications, glyoxal $40 \% \mathrm{w} / \mathrm{w}$ aqueous solution was purchased from Alfa Aesar and made up to required concentrations with deionised (DI) water. Aqueous solutions of $\mathrm{AgNO}_{3}, \mathrm{NaOH}$ and $\mathrm{HCl}$, purchased from Sigma-Aldrich, were made up to the required concentrations with deionised (DI) water. Polystyrene latex beads $(0.3 \mu \mathrm{m})$ were purchased from Sigma-Aldrich for use as tracer particles in $\zeta$-potential measurements.

For cell studies Dulbecco's Modified Eagle Medium (DMEM, GlutaMAX ${ }^{\mathrm{TM}}$ ), non-essential amino acids, sodium pyruvate, trypsin $(0.05 \%)$ and trypan blue $(0.4 \%)$ were purchased from Gibco and stored at $4{ }^{\circ} \mathrm{C}$. Foetal bovine serum (FBS, non-USA origin), MG-63 cells, Pluronic F127 and formaldehyde (37\% in $10-15 \%$ methanol in $\mathrm{H}_{2} \mathrm{O}$ solution) were purchased from Sigma-Aldrich. Phosphate buffer solution (PBS, $0.1 \mu \mathrm{m}$ sterile filtered) was purchased from HyClone, and 6-diamidino-2-phenylindole (DAPI), phalloidinFITC and penicillin streptomycin from Life Technologies. Norland optical adhesive 63 was purchased from Norland Products. All materials were used as received.

Surface modification by derivitisation

Following the semi dry procedure described for modification of cellulose powder by Zaman et al. (Zaman et al. 2012), cellulose films were cationically modified with GTMAC. These GTMAC modified films are referred to as "cationic cellulose".
Fourier Transform Infrared spectroscopy (FTIR), performed on a Perkin Elmer Spectrum 100 FTIR spectrometer, was used to confirm the presence of quaternary ammonium functional groups on cationic cellulose films. FTIR measurements were previously substantiated by ${ }^{1} \mathrm{H}^{13} \mathrm{C}$ cross polarisation/magic angle spinning NMR spectroscopy (Courtenay et al. 2017) (Figs. S1, S2, supplementary information). The degree of substitution (DS) was determined by conductometric titration (Fig. S3) against $\mathrm{AgNO}_{3}(\mathrm{aq})$ solutions, conducted in triplicate.

Structural modification by crosslinking

Cellulose dialysis membrane films, $\sim 1 \mathrm{~g}$, were washed thoroughly in DI water and soaked in $50 \mathrm{~mL}$ glyoxal solution $(0.5,1,3,6$, or $12 \mathrm{wt} \%$ as required) for $3 \mathrm{~h}$. The still-wet films were heated at $160{ }^{\circ} \mathrm{C}$ for $1 \mathrm{~h}$ and washed with copious quantities of DI water. Following this reaction, the films were cationised using the same method as previously reported (Courtenay et al. 2017) with a GTMAC:anhydroglucose unit (AGU) ratio of $2: 1$, and the resultant degree of substitution determined as above.

The degree of crosslinking (DXL) was determined by HPLC analysis following a method adapted from Schramm et al. (Schramm and Rinderer 2000). Briefly, dry crosslinked cellulose films $(0.2-0.4 \mathrm{~g})$, accurately weighed, in $20 \mathrm{~mL} 4 \mathrm{M} \mathrm{NaOH}$ were heated at $100{ }^{\circ} \mathrm{C}$ for $15 \mathrm{~min}$ to hydrolyse crosslinks, generating glycolic acid. The resultant solutions were filtered (PTFE, $0.45 \mu \mathrm{m}$ disposable filter) and the concentration of glycolic acid in each solution was determined by HPLC analysis: aminex organic acid analysis column (HPX-87H, $300 \mathrm{~mm} \times 7.8 \mathrm{~mm}, \quad 50{ }^{\circ} \mathrm{C}$ ), mobile 
phase $0.01 \mathrm{M} \mathrm{H}_{2} \mathrm{SO}_{4}(0.6 \mathrm{~mL} / \mathrm{min})$, and $\mathrm{UV}$ detector $\lambda=210 \mathrm{~nm}$ (Figs. S4, S5).

Once the mass of glyoxal present in the crosslinked films was determined (using calibration curve, Fig. S6) the DXL was calculated using the following equation: Degree of Crosslinking $\%=\left[\frac{162.15 \times \text { Mol }_{\text {glyoxal }}}{w-\left(58.04 \times \text { Mol }_{\text {cellulose }}\right)}\right] 100$

where Mol $_{\text {glyoxal }}$ is the amount of glyoxal detected by

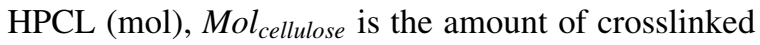
cellulose present (mol) and $w$ is the weight of the dried crosslinked cellulose sample $(\mathrm{g}), 162.15$ is the $M_{w}$ of the AGU and 58.04 is the difference in $M_{w}$ between the AGU and crosslinked AGU bearing a glyoxal group. Triplicate samples were analysed for each material and an average reported (Fig. 1).

Scaffold surface characterisation

The surface $\zeta$-potentials of unmodified and cationic cellulose films were measured at $25^{\circ} \mathrm{C}$ using a Malvern Zetasizer surface $\zeta$-potential cell. Samples were cut to the appropriate size, mounted onto the sample plate and aligned with the laser. The measured electrophoretic mobility of $300 \mathrm{~nm}$ tracer particles in dispersion was recorded at varying distances from the sample surface to determine the surface $\zeta$-potentials. Triplicate film samples were analysed for each material, the measurement repeated fifteen times per sample and an average reported.

Scanning probe microscopy was employed to obtain topography and capacitance gradient $(d C / d z)$

(a)

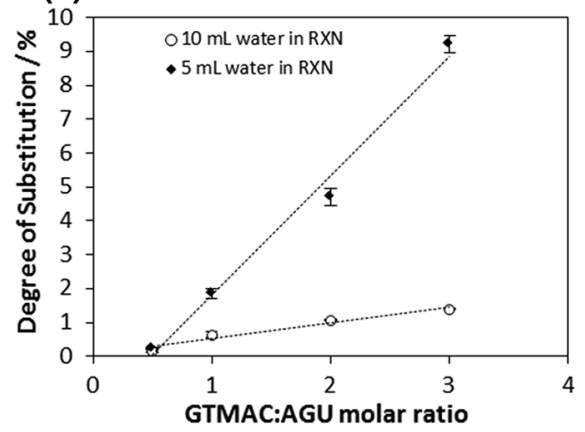

Fig. 1 a DS per anhydroglucose repeat unit for the modified cellulose films determined by conductometric titration. Varying DS is achieved by using different GTMAC molar ratios and volume of water in reaction $(n=3$; error bars show standard images of unmodified, and cationic, cellulose films using a Park NX-10 atomic force microscope (Gouveia and Galembeck 2009; Ferreira et al. 2015). Kelvin force and capacitance coupling measurements were conducted in parallel by applying an electric AC signal at $17 \mathrm{kHz}$ to the metal-coated cantilever-the DC potential was applied to the cantilever to nullify the AC signal at $17 \mathrm{kHz}$ to determine the electric potential of the sample. The capacitance gradient $(\mathrm{dCl}$ $d z$ ), or capacitance coupling, of the tip to the sample was proportional to the second harmonic of the AC signal $(34 \mathrm{kHz})$. The AFM images were processed and analysed using Gwyddion software (Necas and Klapetek 2012) and the "1D height analysis" function of the programme used to calculate the capacitance coupling signal distribution on the film.

The degree of penetration of the GTMAC reagent solution and hence the depth of penetration of modification into the bulk cellulose was evaluated by confocal florescence microscopy. Cationic films with DS of $0.6,2.4,4.7$ and $9.2 \%$ were cut into $0.5 \times 1 \mathrm{~cm}$ strips, washed and hydrated in $100 \mathrm{~mL}$ DI water, then stained by immersion in a $100 \mu \mathrm{M}$ solution of 5(6)carboxyfluorescein for $30 \mathrm{~s}$, followed by thorough washing in DI water to remove excess dye. The films were secured to a glass slide and viewed using a LSM 510 META confocal laser scanning microscope with an EC-Plan-Neofluor 20x/0.5 PH2M27 lens. An argon laser, $\lambda=488 \mathrm{~nm}$, was used to excite the dyed films. Multiple images acquired at $0.5 \mu \mathrm{m}$ steps in depth were combined in a $z$-stack to determine the depth of dye penetration into the bulk of the film.

(b)

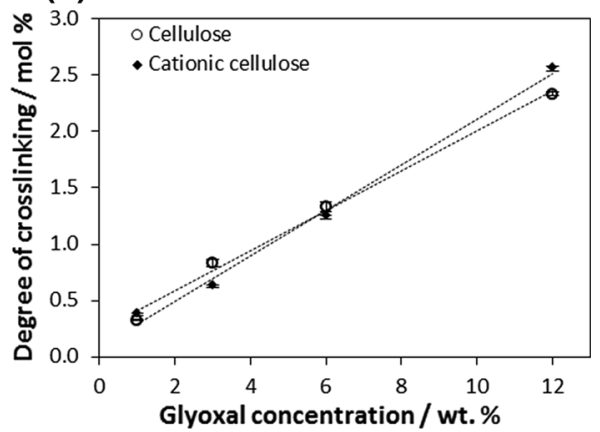

error). b DXL $(\mathrm{mol} \%)$ in unmodified $\left(\mathrm{R}^{2}=0.994\right)$ and cationic cellulose $\left(R^{2}=0.994\right)$ films determined by HPLC $(n=3$, error bars show standard error) 
Scaffold structural characterisation

The bulk elastic modulus of the scaffolds was determined using a Dynamic Materials Analyser (DMA1 STAR ${ }^{\mathrm{e}}$ System, Mettler Toledo). The samples used were unmodified and cationic (DS $=4.7 \pm 0.3 \%$ ) cellulose films, with a range of crosslinking in both sets (DXL $=0-2.6 \%)$. The films (dried at $50{ }^{\circ} \mathrm{C}$ for $24 \mathrm{~h}$ ) were cut into strips $\geq 1.50 \mathrm{~cm}$ in length by $0.50 \mathrm{~cm}$ width and the thickness recorded with a steel digital vernier micrometer calliper. The film strips were gripped between titanium tension clamp sample holders and a preload force of $1 \mathrm{~N}$ was applied to the sample. An offset of $10 \mu \mathrm{m}$ was set at a frequency of $1 \mathrm{~Hz}$ and the elastic moduli were recorded over $5 \mathrm{~min}$. To replicate "hydrated" conditions the relative humidity was set to $80 \%$ using a humidity chamber (MHG, modular humidity generator) and samples equilibrated for $10 \mathrm{~min}$. Five samples were tested for each film and an average reported.

Atomic force microscopy (AFM) was used to characterise the surface shear moduli of films as previously described by Bae et al. (2014, 2016). In brief, to measure shear modulus, films were first presoaked in PBS overnight at room temperature. After removing PBS, cyanoacrylate adhesive was applied to glue each end of the films to the $35 \mathrm{~mm}$ tissue culture dish and the films re-immersed in PBS. Shear modulus was measured in force mode using a Bruker DAFM2X BioScope AFM system. A silicon nitride probe (spring constant, $0.06 \mathrm{~N} \mathrm{~m}^{-1}$ ) with a conical tip (40 $\mathrm{nm}$ in diameter) was used to indent the films; 15 measurements were collected per film sample. To calculate the shear modulus, the first $600 \mathrm{~nm}$ of tip deflection from the horizontal was fit with the Hertz model for a cone for each measurement (Domke and Radmacher 1998). The data were analysed utilising custom MATLAB scripts kindly provided by Professor Paul Janmey.

\section{Cell response}

Cellulose films, modified as described above, were cut into square shapes to fit a Costar ${ }^{\circledR}$ tissue culture well plate, washed, and placed into wells. Loaded plates were sterilised in a Hoefer UVC 500 crosslinker for $15 \mathrm{~min}$, a drop of Norland optical adhesive placed atop the sterilised films, and the films inverted and re- sterilised. Films were hydrated by adding PBS and stored at $4{ }^{\circ} \mathrm{C}$ before cell experiments.

To measure cell attachment, films were incubated with the appropriate cell culture medium for $24 \mathrm{~h}$ at $4{ }^{\circ} \mathrm{C}$, the medium was removed, films seeded with MG-63 cells at a density of 10,000 cells $\mathrm{cm}^{-2}$ and incubated for $1 \mathrm{~h}$ at $37{ }^{\circ} \mathrm{C}$. As a positive control, cells were seeded into empty tissue culture wells. At the $1 \mathrm{~h}$ time point, the medium was removed, cells were washed with two aliquots of PBS to remove unattached cells, remaining cells were fixed with $3.7 \%$ formaldehyde for $15 \mathrm{~min}$ at room temperature, washed twice with PBS, stained with DAPI for $15 \mathrm{~min}$ at room temperature (DAPI stains the nuclei enabling cell counts), washed with PBS and stored in PBS at $4{ }^{\circ} \mathrm{C}$ prior to image acquisition.

Cellulose films were removed from the well plate and inverted on glass microscope slides. Six independent, non-overlapping, fluorescence images of each film were acquired with a $10 \mathrm{X}$ objective on an EVOS optical microscope. Cell numbers were counted using ImageJ software and normalised to the area of the image. Average cell counts from the images were used to determine cell attachment by normalising to the initial seeding density, Eq. 2:

$\%$ cell attachment $=\frac{\text { No. of cells on scaffold }}{\text { Seeding density }} \times 100$

To measure cell adhesion, seeded scaffolds, incubated for $1 \mathrm{~h}$, were centrifuged at $200 \mathrm{rpm}(8 \mathrm{~g})$ for $10 \mathrm{~min}$, cells were fixed, stained with DAPI and attachment determined as described above.

To measure cell morphology, films were seeded with MG-63 cells at 2500 cells $\mathrm{cm}^{-2}$ in serum free DMEM for $1 \mathrm{~h}$ to allow cells to attach without the aid of serum-containing cues. A low cell density was used to reduce cell aggregates on the surface so that individual cell morphologies could be analysed. Control experiments were performed by incubating cells in empty tissue culture well plates. The medium was then removed and replaced with serum containing medium, which is necessary for cell survival. After $24 \mathrm{~h}$, cells were washed twice with PBS, fixed with formaldehyde for $15 \mathrm{~min}$ at room temperature, washed, permeabilised by treatment with $0.1 \%$ Triton-X for $15 \mathrm{~min}$ at room temperature, and washed again with PBS. Cells were stained with FITC- 
phalloidin (diluted 1:100) by incubating for $40 \mathrm{~min}$ at room temperature, washed with PBS, then stored in PBS at $4{ }^{\circ} \mathrm{C}$ prior to image acquisition. Images were acquired as described above and analysis to quantify cell area and aspect ratio was conducted using Image J software, as described by Fardin et al. (2010).

\section{Statistical analysis}

An IBM SPSS Statistics Data Editor was used to perform a one-way analysis of variance (ANOVA) on data sets to determine statistically significant differences between samples at confidence levels of $p<0.001$ (***) $^{* *} p<0.01\left(^{* *}\right)$ and $p<0.05(*)$. Cell morphology data was presented as a box and whisker plot to convey the wide spread of cell aspect ratio and cell area.

\section{Results and discussion}

Working towards the development of easily manufactured tissue engineering scaffold materials that are tunable to specific applications, we have demonstrated that chemical surface modification of cellulose materials, to impart positive surface charge, yielded scaffold materials that allowed ligand free attachment of cells (Courtenay et al. 2017). Here we examine the minimum level of modification required to promote cell attachment and describe the influence of scaffold surface chemistry and mechanics on the adhesion and growth of a human osteosarcoma cancer cell line, MG63. A dual approach, utilising two easily applied chemical modifications was used to modulate the scaffold properties:

- surface charge was regulated by reaction with GTMAC to produce cationic cellulose scaffolds and

- mechanical properties of the bulk and the surface were varied by crosslinking cellulose with glyoxal.

Cellulose films, with DS ranging from 0.2 to $9.2 \%$ (determined by conductometric titration) and DXL ranging from 0.3 to $2.6 \%$ (determined by HPLC analysis), were prepared as 2D scaffolds and MG-63 cell attachment and spreading compared to unmodified films and to tissue culture polystyrene. Understanding how these facilely modified properties influence cell response aids the development of scaffolds that can promote specific, or specialised, cell function needed for proper tissue functionality and morphogenesis (Ismail et al. 2007).

Influence of chemical modification on cell response: cell adhesion

Modulation of surface charge substantially enhanced cell attachment, while crosslinking had little effect (Fig. S7). Cell attachment increases with increasing DS, reaching a value of $90 \%$ (relative to tissue culture polystyrene) at DS of only ca. $1.4 \%$ - a maximum is reached between DS of 1.4 and $2 \%$ and no further enhancement in attachment follows (Fig. 2a). As expected, cells showed little affinity for unmodified cellulose, yet this very low degree of surface modification led to an amplification of cell attachment by almost 3000 times, even in the absence of any matrix proteins, such as foetal bovine serum (FBS), added to the medium.

To test cell adhesion, seeded scaffolds were subjected to centrifugation after the initial cell attachment $(1 \mathrm{~h})$. Centrifugation exposes cells to shear stress, and normalising the cell counts post centrifugation to the original seeding density yields the percentage of cells remaining (Fig. 2b). Cell counts post centrifugation were consistent with cell attachment observations, suggesting that attachment was not an artefact of transient charge/charge interactions, as cells were well adhered to the positively charged cellulose, and that modified scaffolds would support adherent dependent cell behavior, such as cell spreading and protein secretion.

Previously native cellulose has been described as requiring the addition of growth factors, or matrix ligands, functionalised to the cellulose surface, to facilitate cell attachment (Wu et al. 2003; Zou et al. 2001; Pelton 2009), however, we demonstrate that a simplified two-component system (cell and biomaterial) can supersede the usual three-component system (cell, biomolecule and material) required for tissue engineering. This reduces the need to use animal (or even human) derived growth factors, potentially enabling scaffold manufacture, transport and storage and obviating some of the concerns that can arise from use of materials derived from mammalian sources, other than the intended recipient of the engineered tissue. 


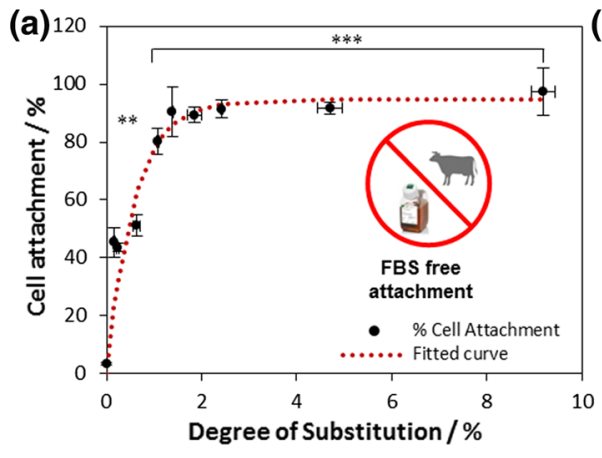

Fig. 2 a The effect of varying degree of substitution on MG-63 cell attachment (after $1 \mathrm{~h}$ incubation at $37{ }^{\circ} \mathrm{C}$ in $5 \% \mathrm{CO}_{2}$ ) on cationically modified cellulose films, with no added ligands adsorbed on the surface ( $\mathrm{n}=3$; error bars show standard error). Minimal surface chemical modification resulted in significant cell attachment to cationic cellulose. Samples marked $* * *$ and ** were significantly different from unmodified cellulose with a $p<0.001$ and $p<0.01$ respectively. b) The percentage of MG-

Influence of chemical modification on cell response: cell morphology

Cell spreading (morphology) is an important measure of the cellular response to a given scaffold. In general, changes in cell shape from spherical to a more flattened disc-like form reflects cells encountering a scaffold surface upon which they can thrive (Lotfi et al. 2013).

Changes in cell spreading were monitored by comparison of the projected cell area and elongation on cationised and unmodified cellulose surfaces, visualised using a fluorescent FITC-phalloidin green stain (Fig. 3a, b). For all cationised films, a significant increase in cell area (from 505-755 to $1186-1529 \mu \mathrm{m}^{2}$ ) and aspect ratio (from $1.2-1.4$ to 1.7-2.1) was observed after $24 \mathrm{~h}$ incubation at $37^{\circ} \mathrm{C}$ in $5 \% \mathrm{CO}_{2}$ (Fig. 3c, d). However, this increase was not statistically different from the cell area and aspect ratio of the very few attached cells on unmodified cellulose. This confirmed that MG-63 cells not only attached to, but also began to spread on, the cationic surface. After an initial increase in cell area due to cells flattening on the surface, the area will not necessarily increase further as cells spread out (Fig. S12). Therefore, the change in cell aspect ratio was considered to be a more relevant measure of spreading as it reflects the elongation, not the flattening, of attached cells. Interestingly, the level of cationisation of the surface did not appear to influence

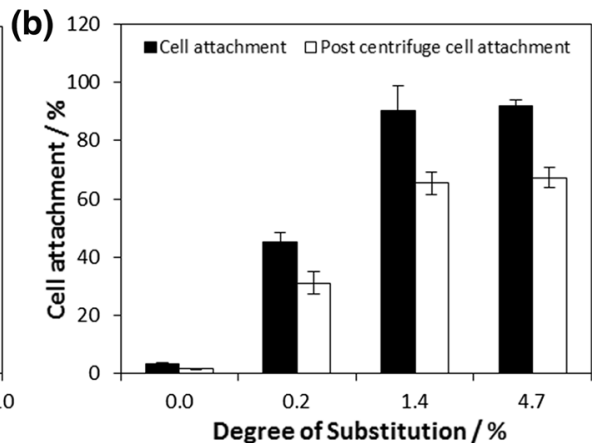

63 cells attached to modified cellulose films after centrifugation at $8 g(\mathrm{n}=3$ and error bars show standard error). There was no statistical difference between the cell attachment values before and post centrifugation for the modified films. The trend in increasing attachment onto films with up to ca $1.4 \%$ DS, followed by a plateau, was mirrored after the seeded scaffolds were subjected to shear, indicating good cell adhesion

the cell morphology, suggesting that changes to the structural properties of the scaffold are required to further modulate spreading. This was achieved by crosslinking and we return to this discussion later. Cell area initially increases upon attachment due to the flattening of the cells, however.

Modulation of scaffold properties: cationisation

It is hypothesised that enhanced cell attachment arose, at least in part, from a change in surface charge from negative to positive upon derivatisation and introduction of tetra-alkylammonium groups. To test this hypothesis, and to gain an understanding of the criteria for cell attachment, materials were characterised with respect to surface charge and capacitance using $\zeta$ potential and electric force microscopy measurements. (Changes in bulk elastic modulus and surface roughness had been discounted, as no significant differences were measured between modified and unmodified materials, Figs. S9, S10).

The measured $\zeta$-potential for unmodified cellulose films was $-36 \pm 4 \mathrm{mV}$, similar to values reported previously (Hasani et al. 2008; Zaman et al. 2012), but, upon the addition of quaternary ammonium moieties, the surface $\zeta$-potential became less negative, continuing to increase and becoming positive, $9 \pm 2 \mathrm{mV}$, at $1.85 \%$ DS (Fig. 4a). Further derivatisation led to further increase in positive surface charge measured by $\zeta$-potential, but values plateaued at $23 \pm 4 \mathrm{mV}$ at 
(a)

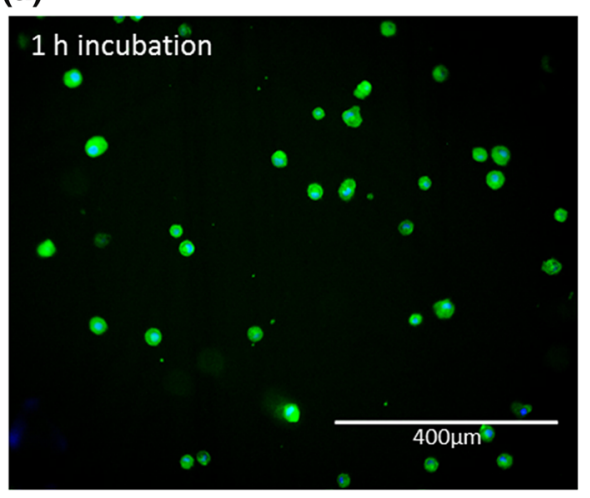

(c)

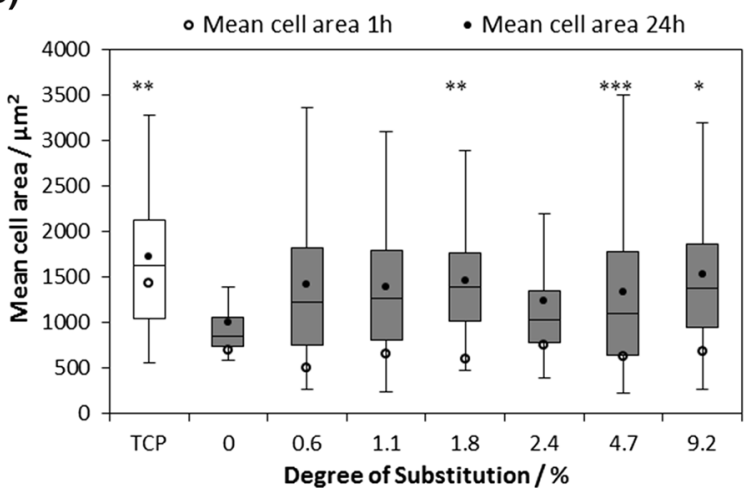

Fig. 3 a Optical microscopy images of MG-63 cells spreading on cationic cellulose $\left(9.19 \%\right.$ DS) after incubation at $37{ }^{\circ} \mathrm{C}$ in $5 \%$ $\mathrm{CO}_{2}$ for $1 \mathrm{~h}$ (left) and $24 \mathrm{~h}$ (right). Attached cells were stained with DAPI (blue) and FITC-phalloidin (green) to highlight the cell nuclei and membranes respectively (scale bar $=400 \mu \mathrm{m}$ ). b A schematic illustrating the measurements used to determine cell aspect ratio from fluorescence images, using ImageJ software. c, d The change in cell area and aspect ratio after $24 \mathrm{~h}$ incubation at $37{ }^{\circ} \mathrm{C}$ in $5 \% \mathrm{CO}_{2},(\mathrm{n}=24-435$; error bars

only $2.42 \%$ DS [reflecting values reported previously for cellulose nanocrystals (Hasani et al. 2008; Song et al. 2008)], suggesting complete saturation of available surface reactive groups. A novel observation here is that this trend is reflected in the affinity of MG63 cells for the surface, with no further increase in numbers of cells adhered to the scaffold surface above DS of between ca. 1.8 and $2.4 \%$.

The change in surface capacitance coupling, $d C / d z$, measured by electric force microscopy, supported the surface $\zeta$-potential findings, reflecting the observed trend. This property, $d C / d z$, is proportional to the electric constant at the surface, however, the value measured by electric force microscopy (EFM) is independent of sign, as the instrument measures the (b)

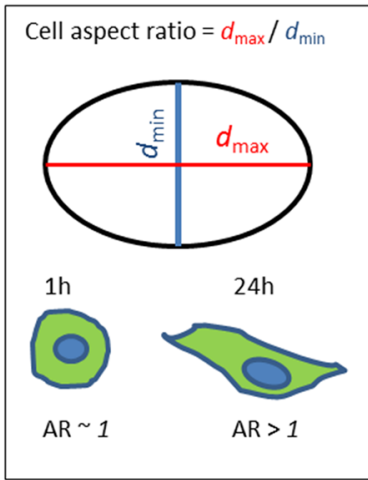

(d)

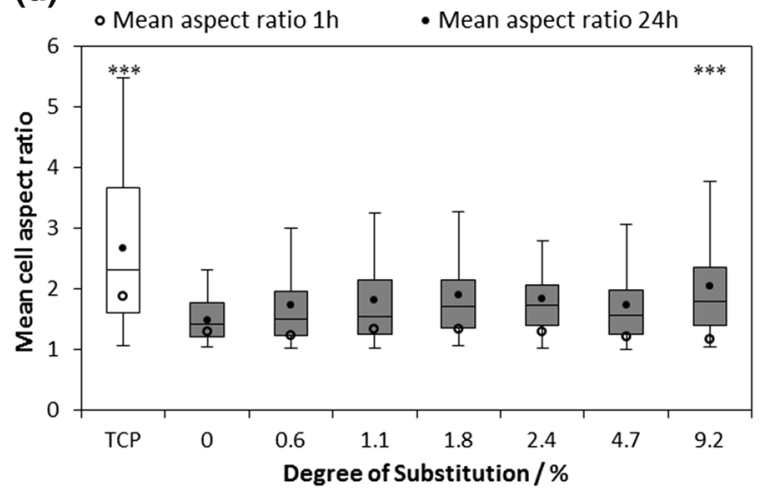

show standard error) demonstrated spreading and expansion of MG-63 occurred on the cationic cellulose scaffolds. The control scaffold was treated tissue culture plastic and cells on this surface exhibited an average area of $1725 \pm 129 \mu^{2}$ and an aspect ratio of $2.68 \pm 0.17$. Samples marked $* * *$, $* *$ and $*$ are significantly different from unmodified cellulose with $p<0.001, p<0.01$ and $p<0.05$ respectively. This data has also been presented in a bar graph in Fig S13. (Color figure online)

force between the charged tip and the electrical field emanating from the sample. Therefore, surfaces of similar absolute charge density (negative or positive) would yield similar $d C / d z$. Unmodified cellulose has a $d C / d z$ of $6.4 \pm 0.25 \mathrm{AU}$, which, upon introduction of quaternary ammonium groups, decreases to a minimum of $3.0 \pm 0.2 \mathrm{AU}$ at $1.39 \% \mathrm{DS}$. $\zeta$-potential shows a charge inversion (from negative to positive), which is reflected in the $d C / d z$ values beyond this \% DS. With further increased DS, measured $d C / d z$ rises and $\zeta$-potential continues to increase reaching $5.5 \pm 0.1$ $\mathrm{AU}$ and $23 \pm 2 \mathrm{mV}$ at $2.42 \% \mathrm{DS}$, whereafter both values plateau [in agreement with the value of 5.9 AU that we previously measured for cationic bacterial cellulose (Courtenay et al. 2017)]. Thus, it appears 


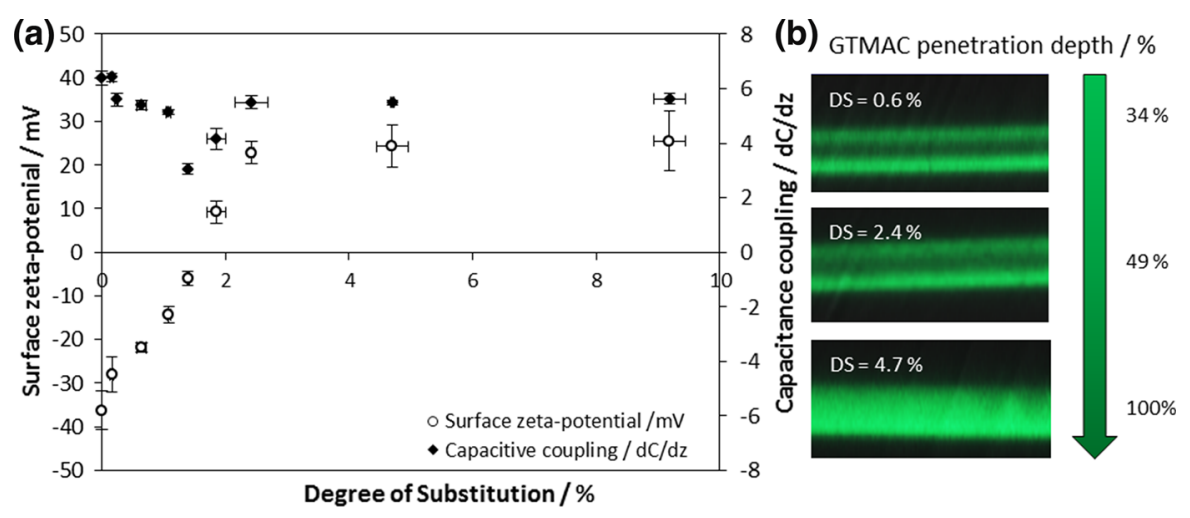

Fig. 4 a $\zeta$-potential and capacitance coupling measurements on cationic cellulose films indicated that, initially, increasing DS was correlated to increasing positive charge on the film surface, but a plateau in the surface charge properties was observed after 2.4\% DS. Capacitive coupling between an EFM tip and cationic cellulose surface was generated by a 1D statistical height analysis across a $10 \mu \mathrm{m}^{2}$ sample surface area $(n=3-5$; error

that, once reactive groups on the surface of the films are reacted, i.e. surface saturation is achieved, increases in measured DS reflect penetration of the GTMAC reagent into the film to greater depth, as illustrated in the confocal microscopy images (Fig. 4b).

It is instructive to consider the mechanism by which MG-63 cells adhere and the evidence suggests that favourable ionic interactions between positively charged scaffolds and the net negatively charged phospholipid groups present in the mammalian cancerous cell membrane (Song et al. 2008) are responsible for the initial "attraction" and attachment of cancer cells to the surfaces. Furthermore, using Pluronic F127 as a blocker of non-specific cell/substrate binding interactions had negligible impact on the levels of cell attachment on cationic cellulose, whereas it did reduce attachment on tissue culture plastic (Fig. S8). Moreover, MG-63 cells have been reported previously to attach onto chitosan scaffolds, which can be a positively charged polymer at some pHs ( $\mathrm{Li}$ et al. 2005). This supports the hypothesis that cell attachment on cationic cellulose scaffolds is "surface charge driven" (Li et al. 2014; Schweizer 2009). Importantly, this response should be general (not restricted to cancerous cells or pathological state of the cell), as many cell types exhibit the same net negative charge on their plasma membranes from the phospholipids constituting the plasma membrane, so would be expected to adhere, attaching to the bars show standard error). b The depth of derivitisation by GTMAC was determined by staining the cationic cellulose with 5(6)-carboxyfluorescein. Constructing a z-stack from confocal microscopy images of films with varying DS revealed that the cationic derivatisation penetrates into the bulk of the cellulose after surface saturation is reached. (Color figure online)

positively charged cellulose substrate. Studies with various cell types and pathological states are currently being investigated to explore this further.

Modulation of scaffold properties: crosslinking

Glyoxal was chosen in this study as a chemical crosslinker due to its low toxicity to mammalian cells and ability to finely regulate the elastic moduli of the scaffolds (Ramires et al. 2010; Wang and Stegemann 2011). Both unmodified and cationic cellulose films were cured in glyoxal solutions (1-12 wt \%) to achieve films with a range of crosslinking determined by HPLC (Figs. S4-S6). Quantifying the glyoxylic acid concentration post base hydrolysis enabled the DXL to be calculated. The DXL ranged from 0.3 to $2.6 \%$ (controlled by initial glyoxal concentration), with minimal difference between the starting cationic or unmodified cellulose films.

Crosslinking of cationic cellulose films increased both bulk elastic modulus and surface shear modulus (Fig. 5a). The effect on the surface shear modulus was greater, which is significant, as the surface shear modulus more closely reflects the scaffold property defining the micro-environment at the cell-scaffold interface. The mechanical properties of the scaffolds could be tuned to further regulate cell response on the cationic scaffolds (Fig. 5b).

The bulk elastic modulus for the unmodified cellulose film (Fig. S10) was $2677 \pm 195 \mathrm{MPa}$ which 


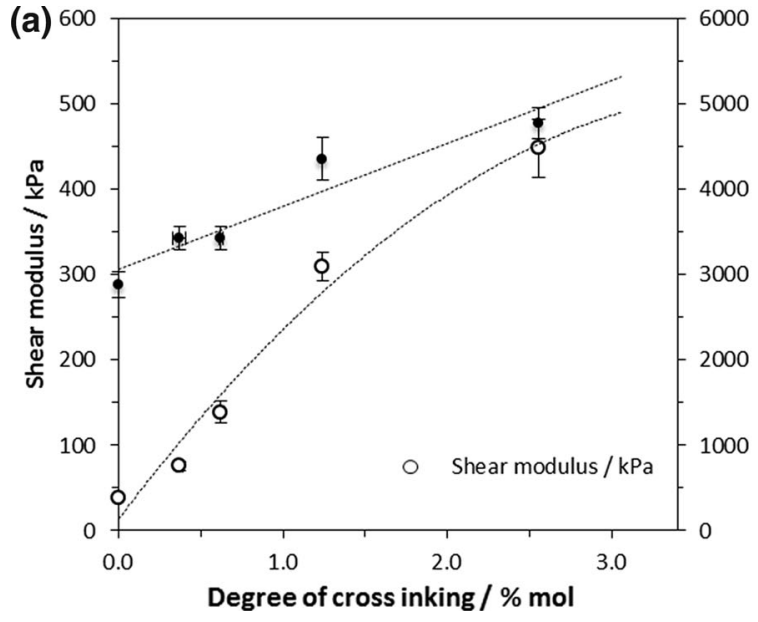

Fig. 5 a Crosslinking of cationic (and unmodified) cellulose films lead to an increase in the bulk elastic modulus (measured on samples equilibrated at $80 \%$ relative humidity, $\mathrm{n}=5$, error bars show standard error, cationic cellulose, $\left.R^{2}=0.907\right)$ and surface shear modulus $(n=4$; error bars show standard error, cationic cellulose, $R^{2}=0.989$ for data fitted to a logarithmic expression). b Change in MG-63 cell aspect ratio on cationic cellulose scaffolds (DS 4.7\%) with increasing surface shear modulus, after $24 \mathrm{~h}$ incubation at $37^{\circ} \mathrm{C}$ in $5 \% \mathrm{CO} 2(\mathrm{n}=51-116$, error bars show standard error). Modulating the structural

rose to $4775 \pm 182 \mathrm{MPa}$ at a DXL of $2.6 \mathrm{~mol} \%$ [comparable with values of $3917 \mathrm{MPa}$ for crosslinked cellulosic materials previously reported (Retegi et al. 2010; Qi et al. 2009)]. Prior to crosslinking, cationic cellulose films exhibited elastic moduli very similar to that of unmodified cellulose, indicating that the integrity of the bulk films was not compromised by the cationisation reaction. As expected, crosslinking stiffens the cellulose films [and reduces swelling when exposed to moisture (Quero et al. 2011)], but, notably (and unexpectedly) the influence of crosslinking on the surface shear moduli was significantly greater than the effect on the bulk. An almost tenfold increase in surface shear modulus occurred upon crosslinking unmodified films (Fig. S11); from $38 \pm 2$ to $332 \pm 37 \mathrm{kPa}$ and this trend was reflected for cationised films, although the shear modulus values differed at higher degrees of crosslinking, $448 \pm 35 \mathrm{kPa}$ versus $332 \pm 37 \mathrm{kPa}$. It is postulated that the chemical surface modification enhances crosslinking efficiency at the surface, either by more efficient reaction (with the introduced secondary alcohol beta to an ether and quaternary ammonium group), or by enhanced swelling, in the aqueous glyoxal solution, of the modified surface layer.

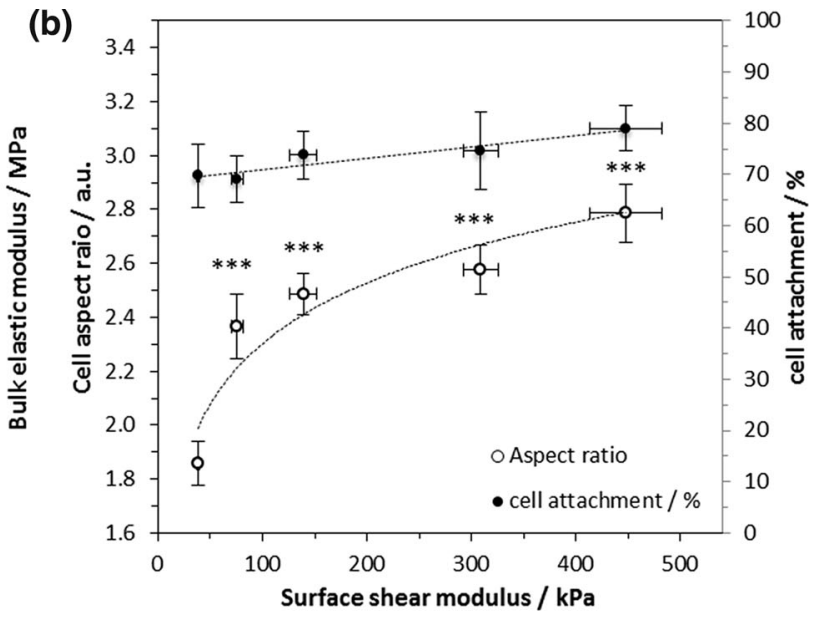

properties of the scaffolds through glyoxal crosslinking had minimal effect on cell attachment, but a significant influence on the degree of cell spreading observed after $24 \mathrm{~h}$ incubation. Untreated cellulose scaffolds had an average cell aspect ratio of $1.86 \pm 0.1$, which increased significantly increased upon crosslinking. MG-63 cells, incubated on tissue culture polystyrene, were used as the control: average cell area $1725 \pm 129 \mathrm{~cm}^{2}$ and aspect ratio 2.68. Samples marked $* * *$ were significantly different from non-crosslinked cationic cellulose with $p<0.001$

Cell attachment was not significantly altered upon increase in elastic, or surface shear moduli, thus, surface charge was deemed to have the greatest impact on facilitating cell attachment. However, changes in cell morphology, as measured by aspect ratio were much more dramatic.

Influence of structural modification on cell response: cell morphology

The significantly greater effect of crosslinking than cationisation on cell elongation, and thus aspect ratio, is illustrated in Fig. 6a, b. Substrate stiffness has been previously reported, by Bae and co-workers, to activated FAK signalling, stimulating $\mathrm{N}$-cadherin expression and increased cell spreading (Mui et al. 2015) and the effect of stiff tissue culture plastic on cell spreading is known: normal adherent cells probe elasticity as they anchor and pull on their surrounding and it has been demonstrated that, on stiffer materials, tactile sensing of the substrate by fibroblast cells feeds back on adhesion and cytoskeleton development, resulting in stronger adhesion and cell spreading (Georges and Janmey 2005; Engler et al. 2006). Therefore, modulating the scaffold mechanics can be 

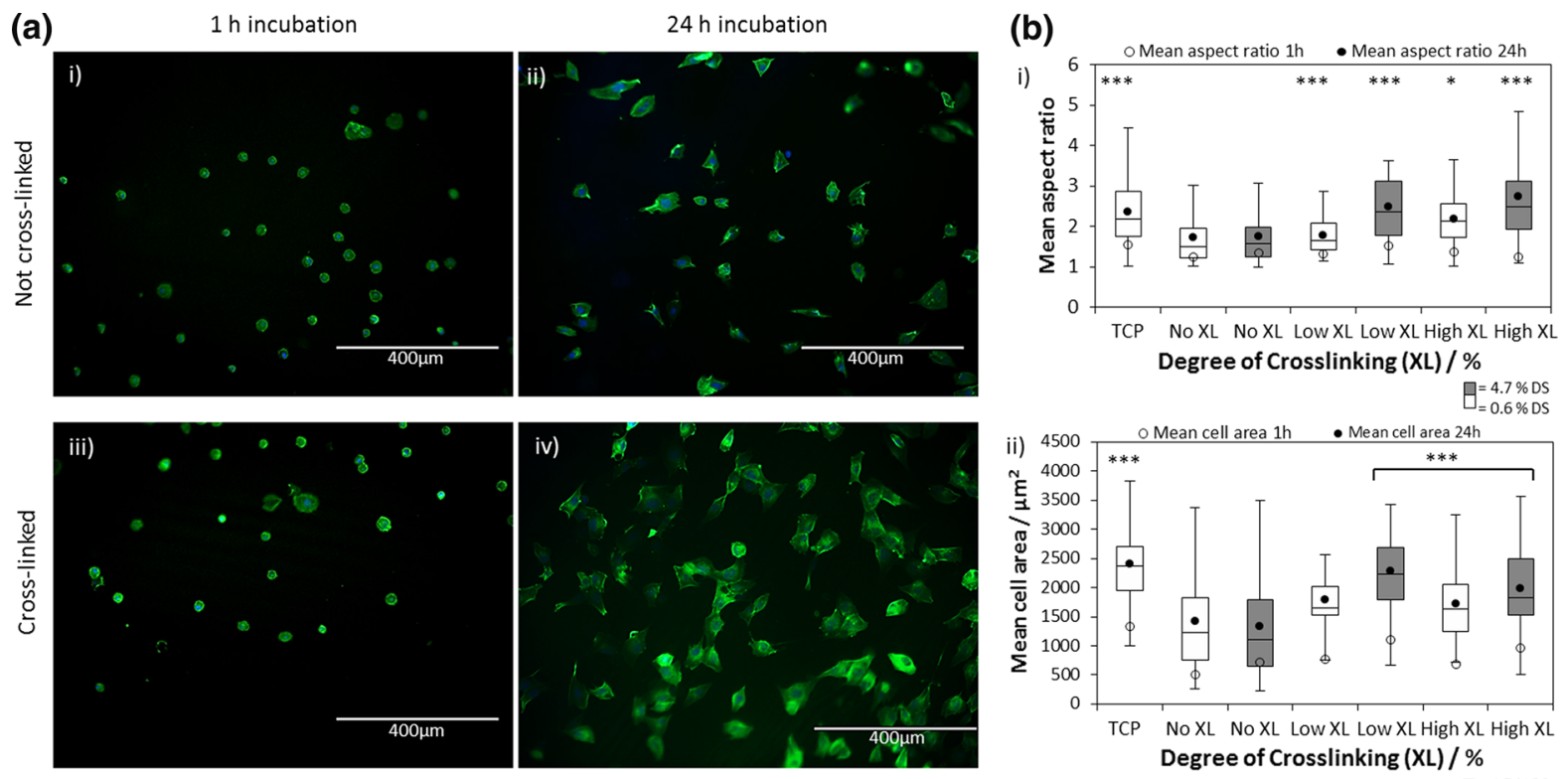

$\mathrm{G}=4.7 \% \mathrm{DS}$
$=0.6 \% \mathrm{DS}$

Fig. 6 a Optical microscope image of cells adhered to cationic cellulose scaffold after incubation at $37{ }^{\circ} \mathrm{C}$ and $5 \% \mathrm{CO}_{2}$ : (i) $1 \mathrm{~h}$ cationic cellulose, (ii) $24 \mathrm{~h}$ cationic cellulose, (iii) $1 \mathrm{~h}$ crosslinked cationic cellulose and (iv) $24 \mathrm{~h}$ crosslinked cationic cellulose. The DS used was $4.7 \%$ and DXL was $2.6 \%$. (The blue coloured structures are the DAPI stained nuclei and green staining, with 5(6)-carboxyfluorescein.) Scale bar $=400 \mu \mathrm{m}$. MG-63 cells appeared to spread out more on the stiffer cationic cellulose scaffolds crosslinked with glyoxal. b Influence of DS and DXL on MG-63 morphology; cell area (i) and aspect ratio (ii) on cationic cellulose scaffolds (DS 0.6

used to further regulate cell response. It is recognised that cell response may vary from cell line to cell line, however, in this study MG-63 cells were used to probe the scaffold mechanics as they are robust yet behave in a manner similar to an osteoblast cell phenotype (Clover and Gowen 1994). Furthermore, MG-63 cells have been shown to spread on chitosan scaffolds with similar, or greater, stiffness than the cationic cellulose scaffold (Li et al. 2005). In this case it is possible to regulate cell attachment and spreading through modulating the scaffold surface charge and mechanics. Soft scaffolds do not provide enough resistance to counterbalance the tension generated by anchored MG-63 cells; as a result fewer focal adhesions are formed and cells retain their spherical shape (Georges and Janmey 2005; Engler et al. 2006). It has been suggested that MG-63 cells form stronger adhesions to stiffer scaffolds due to increased shear stress exerted on the actin fibres as they contract, resulting in a and $4.7 \%)$ treated with varying glyoxal concentrations $(0,1,6$ $\mathrm{wt} \%)$ after $24 \mathrm{~h}$ incubation at $37{ }^{\circ} \mathrm{C}$ in $5 \% \mathrm{CO}_{2},(\mathrm{n}=38-193$; error bars show standard error). Cell images were analysed by ImageJ to calculate the average cell aspect ratio and area. Tissue culture plastic was used as a control, which had an area of $1725 \pm 129 \mathrm{~cm}^{2}$ and an aspect ratio of 2.37. Samples marked $* * *, * *$ and $*$ were significantly different from uncrosslinked cationic cellulose with $p<0.001, p<0.01$ and $p<0.05$ respectively. This data has also been presented in a bar graph in Fig S14. (Color figure online)

greater degree of spreading and increase cell-ECM interface area (Gumbiner 1996).

As no statistically significant effect on cell spreading was observed on moderately cationised cellulose compared to the unmodified cellulose scaffolds, crosslinking was used to stiffen the scaffolds in order to regulate cell spreading. To assess the influence of crosslinking on cell spreading, a cationised cellulose film, with low DS, was used to facilitate the cell attachment only, thus allowing the effect of crosslinking and further cationisation to be determined. The effect of increased scaffold stiffness, particularly at the surface, is important as, once cells have attached to the scaffold, responses such as: migration, proliferation and differentiation (in the case of a stem cells) are all initiated by a change in morphology of the attached cell, i.e. elongation of the cell through spreading. Thus, the ability to tune the mechanical properties of cationic cellulose scaffolds by glyoxal crosslinking in 
order to regulate cell response, demonstrated here, could provide advantages in clinical application, complementing approaches such as blending with hard particles (Jiang et al. 2008), or increased fibril density in bacterial cellulose (Watanabe and Yamanaka 1995; Hult et al. 2003; Bodin et al. 2006).

Thus, we have demonstrated that cellulose can form a promising and simple to modify cell scaffold material and that the combination of chemical surface modification, to introduce positive surface charge, and crosslinking, to modulate scaffold surface stiffness, provides cells with the necessary signaling required for cell attachment and spreading. It has been previously reported that the MG-63 cell line is a representative model of the osteoblast phenotype and can be used to investigate osteoblast function (Clover and Gowen 1994). The values obtained for variously crosslinked cationic cellulose, with surface shear modulus ranging from 40 to $450 \mathrm{kPa}$, suggests that these scaffolds could mimic myocytes of skeletal muscle and osteogenic environments, which have the potential to be used to generate functional musculoskeletal tissue (Janmey and Miller 2011).

Further, modulated spreading suggests opportunities in differentiation of MSCs, given their propensity to differentiate into various cell types guided by scaffold elasticity - a range of scaffold types could be devoloped to facilitate the production of different lineages, for example, soft hydrogels to rigid composites suitably mimicking brain and musculoskeletal tissue respectively (Engler et al. 2006). This offers potential advantages in:

- scaffold production (no sensitive proteinaceous components that can be prone to contamination or requiring special storage);

- scaffold use (mitigation of personal sensitivities, e.g. veganism, pertaining to use of animal derived materials); and

- clinical applications: these functionalised scaffolds could be seeded with cells and implanted into the patient without ligand pre-treatment prior to cell seeding. Once cells were adherent to the implant these could begin to produce their own extracellular matrix and would be supported by the in vivo environment.

\section{Conclusions}

Tailored functionalised biomaterials based on cationic, crosslinked cellulose have been developed and demonstrated to support cell attachment and spreading, without the use of matrix proteins. Derivatisation of cellulose surfaces with the epoxide GTMAC-to yield positively charged cellulose surfaces-enables both attachment and spreading of cells directly on cellulose scaffolds. No added proteins, or ligands, are required. Modulated crosslinking, with glyoxal, produced materials with variable (and tunable) surface shear moduli that resulted in differential cell spreading, suggesting a simple, but effective mechanism to control response. The chemical reactions required are easily effected and the degree of both cationisation and crosslinking can be controlled. Cationisation does not compromise the integrity of the bulk material and, while crosslinking renders the bulk stiffer, the effect is greatest at the surface, thus the cell/scaffold interface can be tuned without significantly compromising the mechanical strength of the bulk construct; potentially beneficial in complex 3D scaffold constructs designed to mimic a particular organ or biological component. The elastic moduli of the crosslinked scaffolds mimicked that of myocytes and osteogenic tissue, suggesting the potential to develop such materials into tailored scaffolds to produce musculoskeletal tissue from MSCs.

Cell studies demonstrated that cell response could be further regulated by tuning the surface stiffness of the scaffolds. Thus, combining these approaches, of minimal surface modification to enable ligand-free cell attachment and modulation of mechanical properties by crosslinking, with addition of hard particles to form composites, promises to greatly extend the range of cell environments that could be mimicked.

Finally, tuning properties using cellulose as a base material and requiring only two facile chemical modifications at varying levels, offers potential advantages in production: a range of materials could be "dialed-up" and one production method could produce a range a scaffolds, or even a range of properties within one scaffold making production cost effective and enabling scale up of these two-component systems.

Acknowledgments Materials characterisation facilities were provided by the Chemical Characterisation and Analysis 
Facility (CCAF), University of Bath and we acknowledge the assistance of Dr Rémi Castaing. Access to the Park NX10 atomic force microscope was provided by the Brazilian Nanotechnology National Laboratory (LNNano) and Dr Darrell Patterson, University of Bath, kindly provided access to a surface $\zeta$-potential cell. JCC acknowledges funding support from the EPSRC Centre for Doctoral Training in Sustainable Chemical Technology (EP/L016354/1) and research visits to Brazil were facilitated by a Global Innovation Initiative grant from the British Council and the University of Bath International Research Mobility Scheme and a University of Bath-FAPESP Exchange Scheme.

Open Access This article is distributed under the terms of the Creative Commons Attribution 4.0 International License (http:// creativecommons.org/licenses/by/4.0/), which permits unrestricted use, distribution, and reproduction in any medium, provided you give appropriate credit to the original author(s) and the source, provide a link to the Creative Commons license, and indicate if changes were made.

\section{References}

Agrawal CM, Ray RB (2001) Biodegradable polymeric scaffolds for musculoskeletal tissue engineering. J Biomed Mater Res Part A 55:141-150. https://doi.org/10.1002/ 1097-4636(200105)55:2<141:AID-JBM1000>3.0.CO;2-J

Agrawal CM, Ong JL, Appleford MR, Mani G (2014a) Tissue engineering. In: Saltzman MW, Chien S (eds) Introduction to biomaterials-basic theory with engineering applications. Cambridge University Press, Cambridge, pp 341-374

Agrawal CM, Ong JL, Appleford MR, Mani G (2014b) Surface modification. In: Saltzman MW, Chien S (eds) Introduction to biomaterials-basic theory with engineering applications. Cambridge University Press, Cambridge, pp 233-281

Bäckdahl H, Helenius G, Bodin A et al (2006) Mechanical properties of bacterial cellulose and interactions with smooth muscle cells. Biomaterials 27:2141-2149. https:// doi.org/10.1016/j.biomaterials.2005.10.026

Bae YH, Mui KL, Hsu BY et al (2014) A FAK-Cas-Raclamellipodin signaling module transduces extracellular matrix stiffness into mechanosensitive cell cycling. Sci Signal 7:ra57. https://doi.org/10.1126/scisignal.2004838

Bae YH, Liu S, Byfield FJ et al (2016) Measuring the stiffness of ex vivo mouse aortas using atomic force microscopy. $\mathrm{J}$ Vis Exp. https://doi.org/10.3791/54630

Benoit DSW, Anseth KS (2005) Heparin functionalized PEG gels that modulate protein adsorption for hMSC adhesion and differentiation. Acta Biomater 1:461-470. https://doi. org/10.1016/j.actbio.2005.03.002

Berti FV, Rambo CR, Dias PF, Porto LM (2013) Nanofiber density determines endothelial cell behavior on hydrogel matrix. Mater Sci Eng C 33:4684-4691. https://doi.org/10. 1016/j.msec.2013.07.029

Biazar E, Heidari M, Asefnejad A, Montazeri N (2011) The relationship between cellular adhesion and surface roughness in polystyrene modified by microwave plasma radiation. Int J Nanomed 6:631-639. https://doi.org/10. 2147/IJN.S17218

Bodin A, Bäckdahl H, Fink H et al (2006) Influence of cultivation conditions on mechanical and morphological properties of bacterial cellulose tubes. Biotechnol Bioeng 97:425-434. https://doi.org/10.1002/bit

Cao Y, Hoon B, Bianco H, Venkatraman SS (2016) Synthesis of stiffness-tunable and cell-responsive gelatin-poly (ethylene glycol) hydrogel for 3-dimensional cell encapsulation. J Biomed Mater Res Part A 104:2401-2411. https://doi. org/10.1002/jbm.a.35779

Chang H, Wang Y (2011) Cell responses to surface and architecture of tissue engineering scaffolds. Regen Med Tissue Eng Cells Biomater 27:569-588. https://doi.org/10.5772/ 21983

Clover J, Gowen M (1994) Are MG-63 and HOS TE85 human osteosarcoma cell lines representative models of the osteoblastic phenotype? Bone 15:585-591. https://doi.org/ 10.1016/8756-3282(94)90305-0

Courtenay JC, Johns MA, Galembeck F et al (2017) Surface modified cellulose scaffolds for tissue engineering. Cellulose 24:253-267. https://doi.org/10.1007/s10570-0161111-y

Dadsetan M, Pumberger M, Casper ME et al (2011) The effects of fixed electrical charge on chondrocyte behavior. Acta Biomater 7:2080-2090. https://doi.org/10.1016/j.actbio. 2011.01.012

Discher DE, Janmey P, Wang Y-L (2005) Tissue cells feel and respond to the stiffness of their substrate. Science 310:1139-1143. https://doi.org/10.1126/science.1116995

Domke J, Radmacher M (1998) Measuring the elastic properties of thin polymer films with the atomic force microscope. Langmuir 14:3320-3325. https://doi.org/10.1021/ La9713006

Ducheyne P, Qui Q (1999) Bioactive ceramics: the effect of surface reactivity on bone formation and bone cell function. Biomaterials 20:2287-2303. https://doi.org/10.1016/ S0142-9612(99)00181-7

Dugan JM, Collins RF, Gough JE, Eichhorn SJ (2013) Oriented surfaces of adsorbed cellulose nanowhiskers promote skeletal muscle myogenesis. Acta Biomater 9:4707-4715. https://doi.org/10.1016/j.actbio.2012.08.050

Dvir T, Timko BP, Kohane DS, Langer R (2011) Nanotechnological strategies for engineering complex tissues. Nat Nanotechnol 6:13-22. https://doi.org/10.1038/nnano. 2010.246

Engler AJ, Sen S, Sweeney HL, Discher DE (2006) Matrix elasticity directs stem cell lineage specification. Cell 126:677-689. https://doi.org/10.1016/j.cell.2006.06.044

Fardin MA, Rossier OM, Rangamani P et al (2010) Cell spreading as a hydrodynamic process. Soft Matter 6:4788-4799. https://doi.org/10.1039/c0sm00252

Ferreira ES, Lanzoni EM, Costa CAR et al (2015) Adhesive and reinforcing properties of soluble cellulose: a repulpable adhesive for wet and dry cellulosic substrates. ACS Appl Mater Interfaces 7:18750-18758. https://doi.org/10.1021/ acsami.5b05310

Georges PC, Janmey PA (2005) Cell type-specific response to growth on soft materials. J Appl Physiol 98:1547-1553. https://doi.org/10.1152/japplphysiol.01121.2004 
Gouveia RF, Galembeck F (2009) Electrostatic charging of hydrophilic particles due to water adsorption. J Am Chem Soc 131:11381-11386. https://doi.org/10.1021/ja900704f

Gravel M, Gross T, Vago R, Tabrizian M (2006) Responses of mesenchymal stem cell to chitosan-coralline composites microstructured using coralline as gas forming agent. Biomaterials 27:1899-1906. https://doi.org/10.1016/j. biomaterials.2005.10.020

Gumbiner BM (1996) Cell adhesion: the molecular basis of tissue architecture and morphogenesis. Cell 84:345-357. https://doi.org/10.1016/S0092-8674(00)81279-9

Hasani M, Cranston ED, Westman G, Gray DG (2008) Cationic surface functionalization of cellulose nanocrystals. Soft Matter 4:2238-2244. https://doi.org/10.1039/b806789a

Hersel U, Dahmen C, Kessler H (2003) RGD modified polymers: biomaterials for stimulated cell adhesion and beyond. Biomaterials 24:4385-4415. https://doi.org/10. 1016/S0142-9612(03)00343-0

Hollister SJ, Maddox RD, Taboas JM (2002) Optimal design and fabrication of scaffolds to mimic tissue properties and satisfy biological constraints. Biomaterials 23:4095-4103. https://doi.org/10.1016/S0142-9612(02)00148-5

Hult EL, Yamanaka S, Ishihara M, Sugiyama J (2003) Aggregation of ribbons in bacterial cellulose induced by high pressure incubation. Carbohydr Polym 53:9-14. https:// doi.org/10.1016/S0144-8617(02)00297-7

Ismail FSM, Rohanizadeh R, Atwa S et al (2007) The influence of surface chemistry and topography on the contact guidance of MG63 osteoblast cells. J Mater Sci Mater Med 18:705-714. https://doi.org/10.1007/s10856-006-0012-2

Janmey PA, Miller R (2011) Mechanisms of mechanical signaling in development and disease. J Cell Sci 124:9-18. https://doi.org/10.1242/jcs.071001

Jiang L, Li Y, Wang X et al (2008) Preparation and properties of nano-hydroxyapatite/chitosan/carboxymethyl cellulose composite scaffold. Carbohydr Polym 74:680-684. https:// doi.org/10.1016/j.carbpol.2008.04.035

Kular JK, Basu S, Sharma RI (2014) The extracellular matrix: structure, composition, age-related differences, tools for analysis and applications for tissue engineering. J Tissue Eng 5:1-17. https://doi.org/10.1177/2041731414557112

Kumar A, Negi YS, Choudhary V, Bhardwaj NK (2014) Microstructural and mechanical properties of porous biocomposite scaffolds based on polyvinyl alcohol, nano-hydroxyapatite and cellulose nanocrystals. Cellulose 21(5):3409-3426: https://doi.org/10.1007/s10570-0140339-7

Kumar A, Rao KM, Han SS (2017) Synthesis of mechanically stiff and bioactive hybrid hydrogels for bone tissue engineering applications. Chem Eng J 317:119-131. https:// doi.org/10.1016/j.cej.2017.02.065

Kumar A, Rao KM, Kwon SE et al (2017) Xanthan gum/ bioactive silica glass hybrid scaffolds reinforced with cellulose nanocrystals: Morphological, mechanical and in vitro cytocompatibility study. Mater Lett 193:274-278. 10.1016/j.matlet.2017.01.143

Li JM, Menconi MJ, Wheeler HB et al (1996) Precoating expanded polytetrafluoroethylene grafts alters production of endothelial cell-derived thrombomodulators. J Vasc Surg 15:1010-1017
Li Z, Ramay HR, Hauch KD et al (2005) Chitosan-alginate hybrid scaffolds for bone tissue engineering. Biomaterials 26:3919 3928. https://doi.org/10.1016/j.biomaterials.2004.09.062

Li L, Shi X, Guo X et al (2014) Ionic protein-lipid interaction at the plasma membrane: what can the charge do? Trends Biochem Sci 39:130-140. https://doi.org/10.1016/j.tibs. 2014.01.002

Lieberman JR, Daluiski A, Einhorn TA (2002) The role of growth factors in the repair of bone. Biology and clinical applications. J Bone Joint Surg Am 84-A:1032-1044. https://doi.org/10.1359/jbmr.1999.14.11.1805

Lin D, Yang K, Tang W et al (2015) A poly(glycerol sebacate)coated mesoporous bioactive glass scaffold with adjustable mechanical strength, degradation rate, controlled-release and cell behavior for bone tissue engineering. Colloids Surfaces B Biointerfaces 131:1-11. https:// doi.org/10.1016/j.colsurfb.2015.04.031

Lotfi M, Nejib M, Naceur M (2013) Cell adhesion to biomaterials: concept of biocompatibility. In: Pignatello $\mathrm{R}$ (ed) Advances in biomaterials science and biomedical applications. INTECH Open Access Publisher, pp 207-240

Lu P, Weaver VM, Werb Z (2012) The extracellular matrix: a dynamic niche in cancer progression. J Cell Biol 196:395-406. https://doi.org/10.1083/jcb.201102147

Marklein RA, Burdick JA (2010) Controlling stem cell fate with material design. Adv Mater 22:175-189. https://doi.org/10. 1002/adma.200901055

Modulevsky DJ, Lefebvre C, Haase K et al (2014) Apple derived cellulose scaffolds for 3D mammalian cell culture. PLoS ONE 9:e97835. https://doi.org/10.1371/journal. pone.0097835

Mui KL, Bae YH, Gao L et al (2015) N-cadherin induction by ECM stiffness and FAK overrides the spreading requirement for proliferation of vascular smooth muscle cells. Cell Rep 10:1477-1486. https://doi.org/10.1016/j.celrep.2015. 02.023

Necas D, Klapetek P (2012) Gwyddion: an open-source software for SPM data analysis. Cent Eur J Phys 10:18-188. https://doi.org/10.2478/s11534-011-0096-2

Ninan N, Muthiah M, Park IK et al (2013) Pectin/carboxymethyl cellulose/microfibrillated cellulose composite scaffolds for tissue engineering. Carbohydr Polym 98:877-885. https:// doi.org/10.1016/j.carbpol.2013.06.067

Patterson J, Martino MM, Hubbell JA (2010) Biomimetic materials in tissue engineering. Mater Today 13:14-22. https://doi.org/10.1016/S1369-7021(10)70013-4

Pelton R (2009) Bioactive paper provides a low-cost platform for diagnostics. TrAC Trends Anal Chem 28:925-942. https://doi.org/10.1016/j.trac.2009.05.005

Puspasari T, Pradeep N, Peinemann K-V (2015) Crosslinked cellulose thin film composite nanofiltration membranes with zero salt rejection. J Memb Sci 491:132-137. https:// doi.org/10.1016/j.memsci.2015.05.002

Qi H, Cai J, Zhang L, Kuga S (2009) Properties of films composed of cellulose nanowhiskers and a cellulose matrix regenerated from alkali/urea solution. Biomacromol 10:1597-1602. https://doi.org/10.1021/bm9001975

Quero F, Nogi M, Lee KY et al (2011) Cross-linked bacterial cellulose networks using glyoxalization. ACS Appl Mater Interfaces 3:490-499. https://doi.org/10.1021/am101065p 
Ramires EC, Megiatto JD Jr, Gardrat C et al (2010) Biobased composites from glyoxal-phenol matrices reinforced with microcrystalline cellulose. Polímeros 20:126-133. https:// doi.org/10.1590/S0104-14282010005000016

Ranucci CS, Moghe PV (2001) Substrate microtopography can enhance cell adhesive and migratory responsiveness to matrix ligand density. J Biomed Mater Res 54:149-161. https://doi.org/10.1002/1097-4636(200102)54:2<149: AID-JBM1>3.0.CO;2-O

Reddi A (2003) Cartilage morphogenetic proteins: role in joint development, homoeostasis, and regeneration. Ann Rheum Dis 62:ii73-ii78. https://doi.org/10.1136/ard.62.suppl_2. ii73

Retegi A, Gabilondo N, Pena C et al (2010) Bacterial cellulose films with controlled microstructure-mechanical property relationships. Cellulose 17:661-669. https://doi.org/10. 1007/s10570-009-9389-7

Salgado AJ, Oliveira JM, Martins A et al (2013) Tissue engineering and regenerative medicine: past, present, and future. Int Rev Neurobiol 108:1-33. https://doi.org/10. 1016/B978-0-12-410499-0.00001-0

Sannino A, Demitri C, Madaghiele M (2009) Biodegradable cellulose-based hydrogels: design and applications. Materials (Basel) 2:353-373. https://doi.org/10.3390/ma2020 353

Schmedlen RH, Masters KS, West JL (2002) Photocrosslinkable polyvinyl alcohol hydrogels that can be modified with cell adhesion peptides for use in tissue engineering. Biomaterials 23:4325-4332. https://doi.org/10.1016/S0142-9612 (02)00177-1

Schramm C, Rinderer B (2000) Determination of cotton-bound glyoxal via an internal Cannizzaro reaction by means of high-performance liquid chromatography. Anal Chem 72:5829-5833. https://doi.org/10.1021/ac000704r

Schweizer F (2009) Cationic amphiphilic peptides with cancerselective toxicity. Eur J Pharmacol 625:190-194. https:// doi.org/10.1016/j.ejphar.2009.08.043

Sergeeva YN, Huang T, Felix O et al (2016) What is really driving cell-surface interactions? Layer-by-layer assembled films may help to answer questions concerning cell attachment and response to biomaterials. Biointerphases 11:19009. https://doi.org/10.1116/1.4943046

Song Y, Sun Y, Zhang X et al (2008) Homogeneous quaternization of cellulose in $\mathrm{NaOH} / \mathrm{urea}$ aqueous solutions as gene carriers. Biomacromol 9:2259-2264. https://doi.org/ 10.1021/bm800429a

Svensson A, Nicklasson E, Harrah T et al (2005) Bacterial cellulose as a potential scaffold for tissue engineering of cartilage. Biomaterials 26:419-431. https://doi.org/10. 1016/j.biomaterials.2004.02.049

Syverud K, Pettersen SR, Draget K, Chinga-Carrasco G (2015) Controlling the elastic modulus of cellulose nanofibril hydrogels - scaffolds with potential in tissue engineering. Cellulose 22:473-481. https://doi.org/10.1007/s10570014-0470-5

Torres FG, Commeaux S, Troncoso OP (2012) Biocompatibility of bacterial cellulose based biomaterials. J Funct Biomater 3:864-878. https://doi.org/10.3390/jfb3040864

Torres-Rendon JG, Femmer T, De Laporte L et al (2015) Bioactive gyroid scaffolds formed by sacrificial templating of nanocellulose and nanochitin hydrogels as instructive platforms for biomimetic tissue engineering. Adv Mater 27:2989-2995. https://doi.org/10.1002/adma.201405873

Viswanathan P, Ondeck MG, Chirasatitsin S, Nghamkham K et al (2016) 3D surface topology guides stem cell adhesion and differentiation. Biomaterials 8:583-592. https://doi. org/10.1002/aur.1474.Replication

Wang L, Stegemann JP (2011) Glyoxal crosslinking of cellseeded chitosan/collagen hydrogels for bone regeneration. Acta Biomater 7:2410-2417. https://doi.org/10.1016/j. actbio.2011.02.029

Wang N, Butler JP, Ingber DE (1993) Mechanotransduction across the cell surface and through the. Science (80-) 260:1124-1127

Watanabe K, Yamanaka S (1995) Effects of oxygen tension in the gaseous phase on production and physical properties of bacterial cellulose formed under static culture conditions. Biosci Biotechnol Biochem 59:65-68. https://doi.org/10. 1271/bbb.59.65

Watanabe K, Eto Y, Takano S et al (1993) A new bacterial cellulose substrate for mammalian cell culture-a new bacterial cellulose substrate. Cytotechnology 13:107-114. https://doi.org/10.1007/BF00749937

Wu C-Y, Suen S-Y, Chen S-C, Tzeng J-H (2003) Analysis of protein adsorption on regenerated cellulose-based immobilized copper ion affinity membranes. J Chromatogr A 996:53-70. https://doi.org/10.1016/S0021-9673(03)00531-4

Yang J, Bei J, Wang S (2002) Enhanced cell affinity of poly (D,Llactide) by combining plasma treatment with collagen anchorage. Biomaterials 23:2607-2614. https://doi.org/10. 1016/S0142-9612(01)00400-8

Zaborowska M, Bodin A, Bäckdahl H et al (2010) Microporous bacterial cellulose as a potential scaffold for bone regeneration. Acta Biomater 6:2540-2547. https://doi.org/10. 1016/j.actbio.2010.01.004

Zaman M, Xiao H, Chibante F, Ni Y (2012) Synthesis and characterization of cationically modified nanocrystalline cellulose. Carbohydr Polym 89:163-170. https://doi.org/ 10.1016/j.carbpol.2012.02.066

Zou H, Luo Q, Zhou D (2001) Affinity membrane chromatography for the analysis and purification of proteins. J Biochem Biophys Methods 49:199-240. https://doi.org/ 10.1016/S0165-022X(01)00200-7 